\title{
Coccolithophore response to climate and surface hydrography in Santa Barbara Basin, California, AD 1917-2004
}

\author{
M. Grelaud ${ }^{1}$, A. Schimmelmann ${ }^{2}$, and L. Beaufort ${ }^{1}$ \\ ${ }^{1}$ CEREGE, Europôle méditerranéen de l'Arbois, BP80, 13545 Aix-en-Provence Cedex 4, France \\ ${ }^{2}$ Department of Geological Sciences, Indiana University, 1001 East Tenth Street, Bloomington, Indiana, 47405-1403, USA
}

Received: 3 September 2008 - Published in Biogeosciences Discuss.: 28 October 2008

Revised: 5 March 2009 - Accepted: 16 September 2009 - Published: 6 October 2009

\begin{abstract}
The varved sedimentary AD 1917-2004 record from the depositional center of the Santa Barbara Basin (SBB, California) was analyzed with monthly to triannual resolution to yield relative abundances of six coccolithophore species representing at least $96 \%$ of the coccolithophore assemblage. Seasonal/annual relative abundances respond to climatic and surface hydrographic conditions in the SBB, whereby (i) the three species G. oceanica, H. carteri and F. profunda are characteristic of the strength of the northward flowing warm California Counter Current, (ii) the two species G. ericsonii and G. muellerae are associated with the cold equatorward flowing California Current, (iii) and E. huxleyi appears to be endemic to the SBB. Spectral analyses on relative abundances of these species show that all are influenced by the El Niño Southern Oscillation (ENSO) and/or by the Pacific Decadal Oscillation (PDO). Increased relative abundances of $G$. oceanica and $H$. carteri are associated with warm ENSO events, G. muellerae responds to warm PDO events and the abundance of G. ericsonii increases during cold PDO events. Morphometric parameters measured on E. huxleyi, G. muellerae and G. oceanica indicate increasing coccolithophore shell carbonate mass from $\sim 1917$ until 2004 concomitant with rising $p \mathrm{CO}_{2}$ and sea surface temperature in the region of the SBB.
\end{abstract}

\section{Introduction}

Coccolithophores are unicellular pelagic algae that represent a large part of the world ocean's nannophytoplankton and play a significant role in the carbon cycle as major producers of biogenic calcium carbonate. Coccolithophore assemblages are diagnostic for physical and chemical conditions

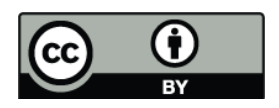

Correspondence to: M. Grelaud (grelaud@cerege.fr) in the photic zone, and therefore fossil coccolithophores in sediments can be used to reconstruct paleoecological and paleoceanographic conditions (Andruleit and Baumann, 1998; Beaufort et al., 1997; Giraudeau et al., 1993; Kinkel et al., 2000; McIntyre and Be, 1967; Nederbragt et al., 2008; Okada and McIntyre, 1979). The inorganic fossil remains of coccolithophores consist of $<20 \mu \mathrm{m}$ calcareous plates called coccoliths. Their small size and large abundance make it possible to sample marine sediment cores at $\mathrm{mm}$ to sub-mm intervals with ultra-high resolution (Grelaud et al., 2009).

This study analyzed coccolithophore assemblages in dated sediment cores from the deep center of the Santa Barbara Basin (SBB) on the North American Pacific margin in the interval from AD 1917 to 2004. The SBB region is hydrographically dominated by the California Current System (CCS), which in turn is modulated by Pacific climate conditions, especially by the El Niño Southern Oscillation (ENSO) and the Pacific Decadal oscillation (PDO). ENSO originates in the tropical Pacific and its warm/cold phases oscillate with a pseudo-frequency of 2 to 7-8 years, whereas warm/cold PDO transitions originate in the north Pacific at $\sim 20^{\circ} \mathrm{N}$ and occur only every 20-30 years. The PDO is commonly described as a long-lived El Niño-like pattern affecting the north Pacific, since both ENSO and PDO exhibit some similar characteristics (Latif and Barnett, 1994; Mantua et al., 1997; Zhang et al., 1997).

Reconstructions of ENSO and PDO prior to the twentieth century are difficult because they require well-dated high resolution proxy records of sufficient length. Nevertheless, several centuries-long reconstructions of ENSO and PDO have been reported. Paleo-ENSO records are based on the oxygen isotopic $\left(\delta^{18} \mathrm{O}\right)$ composition of coral aragonite (Tudhope et al., 2001, 1995) or on the carbon isotopic $\left(\delta^{13} \mathrm{C}\right)$ composition of stalagmite calcite (Frappier et al., 2002), as well as on tree ring data (D'Arrigo et al., 2005; Stahle et al., 1998). These records share a significant common variance and suggest that El Niño events of past centuries share a relatively

Published by Copernicus Publications on behalf of the European Geosciences Union. 


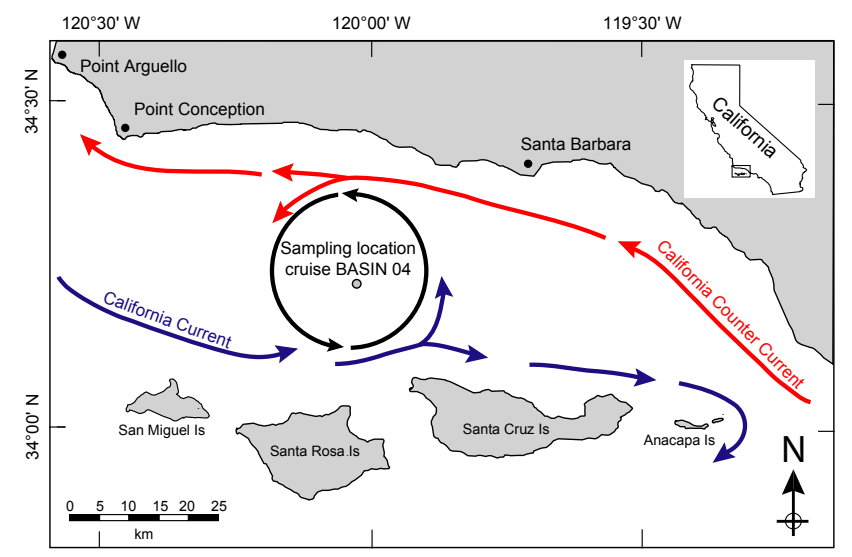

Fig. 1. Sampling location of multicore $1 \mathrm{MC}-3$ during cruise BASIN $2004\left(34^{\circ} 13.41^{\prime} \mathrm{N}, 12^{\circ} 01.53^{\prime} \mathrm{W}\right.$; water depth: $\left.588 \mathrm{~m}\right)$. Arrows denote flow directions of California Current (blue) and California Counter Current (red). Counterclockwise circulation inside the Santa Barbara Basin is indicated by black arrows.

consistent history (Jones and Mann, 2004). However, suitable coral cores and tree ring sequences are rare, relevant analytical methodologies are costly, and techniques require substantial amounts of sample material and effort.

Surveys and studies on nannophytoplankton responses to the El Niño events of 1991-1992 and 1997-1998 in the Southern California Bight and in the SBB indicate that coccolithophores are influenced by El Niño (De Bernardi et al., 2005; Ziveri et al., 1995). Fossil coccolith assemblages can thus serve as a promising paleoceanographic proxy to highlight past El Niño variability, especially in laminated sediments with high resolution.

This study uses relative abundances of sedimentary coccoliths as proxies of climatic and surface hydrographic settings in the SBB from $\sim 1917$ until 2004. Indices of ENSO (Kaplan et al., 1998; Reynolds et al., 2002) and PDO (Mantua et al., 1997; Zhang et al., 1997) have been reconstructed back to the beginning of the 20th century based on instrumental and historic data. We compared our dated, high resolution SBB coccolith record against indices of ENSO and PDO to calibrate coccolith proxies for reconstructions of paleo-El Niño and paleo-PDO conditions in the SBB. Moreover, in the context of modern global warming and ocean acidification due to anthropogenic $\mathrm{CO}_{2}$ release, we investigated the morphometry (size, weight) of selected species of the order Isochrysidales (i.e., E. huxleyi, G. muellerae and G. oceanica) to understand how coccolithophores' carbonate mass is influenced by recent oceanographic global changes.

\section{Materials and methods}

\subsection{Sampling}

Multicore 1MC-3 from the deep center of the SBB $\left(34^{\circ} 13.41^{\prime} \mathrm{N}, 120^{\circ} 01.53^{\prime} \mathrm{W}\right.$, water depth: $\left.588 \mathrm{~m}\right)$ was retrieved in June 2004 during cruise BASIN 2004 (Fig. 1). Two parallel cylindrical cores A and B were retrieved from the multicore. Core A was sectioned in layers with approximately annual to triannual resolution in 2004. The sediment obtained from each sampling interval was freeze-dried and stored (Schimmelmann et al., 1990). Core B was sampled in 2007 after the sediment had lost some water. Sediment of core B was first extruded from its acrylic tube core liner into another core liner featuring a narrow cutout sampling window. After removing the outermost smeared sediment layer, samples were scraped from the window every millimeter with a stainless steel spatula, thus achieving the highest resolution possible. It was not feasible to strictly follow varve boundaries because color and textural differences among varves were often indistinct.

\subsection{Coccolith census}

Smear slides were prepared for all samples of the two cores. 40 view fields from a light microscope (Leica DMRBE) with a $50 \times$ immersion oil objective were captured from each slide by a digital camera ("Spot insight"). Automatic image analysis of each frame resulted in recognition of coccolith species using SYRACO software (Beaufort and Dollfus, 2004; Dollfus and Beaufort, 1999). SYRACO is able to identify more than $96 \%$ of the coccolith assemblages, including the following six species that were enumerated in this study: Emiliania huxleyi, Florisphaera profunda, Gephyrocapsa ericsonii, Gephyrocapsa muellerae, Gephyrocapsa oceanica, and Helicosphaera carteri. A total of more than 600 individuals of these six species were typically counted in each sample. We applied a correction to the count of each species to compensate for SYRACO's inclusion of non-coccolith specimens in the raw data. The final data and the influence of the correction are reproducible (Beaufort and Dollfus, 2004). We prefer relative abundances rather than concentrations or fluxes of coccoliths, since relative abundances are less influenced by dissolution and conditions of sedimentation. It has been shown that relative abundance and flux of coccoliths correlate well (Beaufort and Heussner, 1999; Silva et al., 2008).

\subsection{Age model}

We used the age model of core A (Huguet et al., 2007) to establish that of core B which was subsequently sub-sampled with higher resolution. Because of core compaction during storage, core B was shorter $(26.5 \mathrm{~cm})$ than core A $(32 \mathrm{~cm})$. It was not possible to correlate samples of the same depth between the two cores. The age model of core B was developed in several steps. Briefly, we first measured the coccolith 
(a)

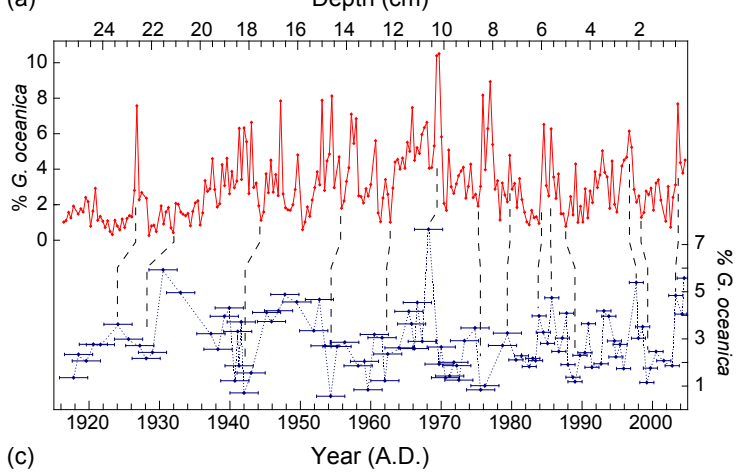

(b) Year (A.D.)

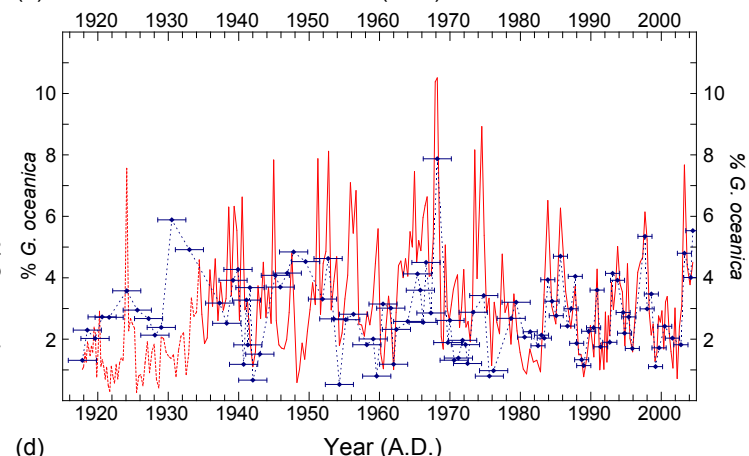

(d)

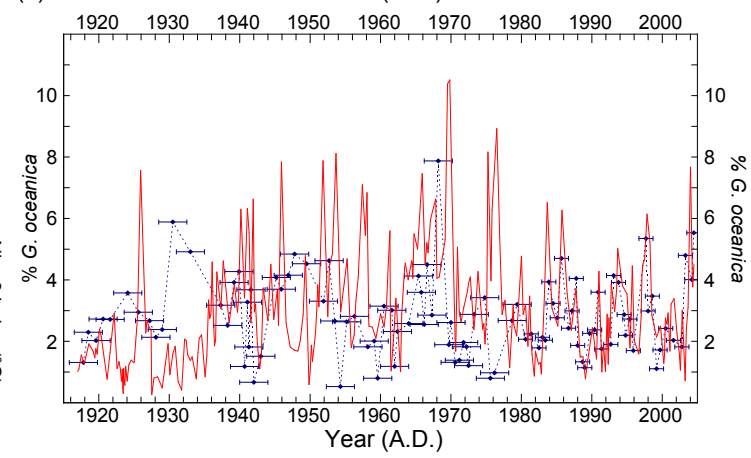

Fig. 2. Development of age model for core B from multicore 1MC-3, cruise BASIN 2004. (a) Correspondence between relative abundance records of G. oceanica in high-resolution core B (red, depth scale) and in low-resolution core A (dotted blue line, age scale). Error bars associated with core A denote the age uncertainty (1 yr after 1980 and 2 yr before 1980; Schimmelmann et al., 2006). (b) Relative abundances of G. oceanica along core B (red) are adjusted to age model of core A (dotted blue line). (c) Relative abundance of G. oceanica in core B adjusted to extended NINO3 index (black) (Kaplan et al., 1998; Reynolds et al., 2002) (data available at http://iridl.ldeo.columbia.edu/ SOURCES/.Indices/.nino/.EXTENDED/.NINO3/). (d) Relative abundances of G. oceanica in core A (blue) and in core B (red, using the final age model).

abundances in leftover sub-sectioned and freeze-dried sediment aliquots from core A that had been used by Huguet et al. (2007). The dating uncertainty for core $A$ is $\sim 2$ years below $1980 \mathrm{AD}$ and $\sim 1$ year for younger sediment. We then measured coccolith abundances in samples extracted from core B. The two coccolith data series from cores A (lower resolution) and $\mathrm{B}$ (higher resolution) were then correlated to each other.

Secondly, we correlated the relative abundance patterns of the tropical coccolithophore species G. oceanica between cores A and B because they are best recognized by SYRACO (Fig. 2a). A total of 72 tie-points were used between the two cores to perform the correlation. Relative abundances of G. oceanica matched cores A and B well between AD 1938 to 2004 (Fig. 2b; 59 tie-points, R2=0.595), but less satisfactorily prior to AD 1938 (Fig. 2b; 13 tie-points, R2=0.193). This correlation provided an approximate, preliminary age model for core B.

Thirdly, we finetuned the chronological relative abundance of G. oceanica of core B to the extended NINO3 index (Kaplan et al., 1998; Reynolds et al., 2002) (Fig. 2c), since (i) earlier studies have shown that high abundances of G. ocean- ica were found during the El Niño event of 1997-1998, while the pre-El Niño period (i.e. 1996) was characterized by very low G. oceanica abundances (De Bernardi et al., 2005); (ii) it has been shown that during El Niño years, the tropical convection center moves to the central and eastern equatorial $\mathrm{Pa}$ cific, leading to a weakening of the North Pacific High and inducing the warming of the California Borderlands through the intensification of the southern California Countercurrent (CCC) (Bograd and Lynn, 2001); and (iii) it was confirmed that the increased G. oceanica coccolith flux in SBB provides evidence for the poleward transport of El Niño's conditions to higher latitudes (De Bernardi et al., 2008).

Finally, the chronology of the high-resolution data series from core B was further adjusted by linking peaks of relative abundance of $F$. profunda to instrumental monthly sea surface temperatures in the SBB. This species prefers strongly stratified waters (De Bernardi et al., 2005, 2008). De Bernardi et al. (2005) showed that $F$. profunda produces high coccosphere fluxes in fall when the water column is stratified with a deep thermocline. This period corresponds to the warmest sea surface temperature (SST) recorded in the SBB. We therefore improved the age model by tuning each year's 


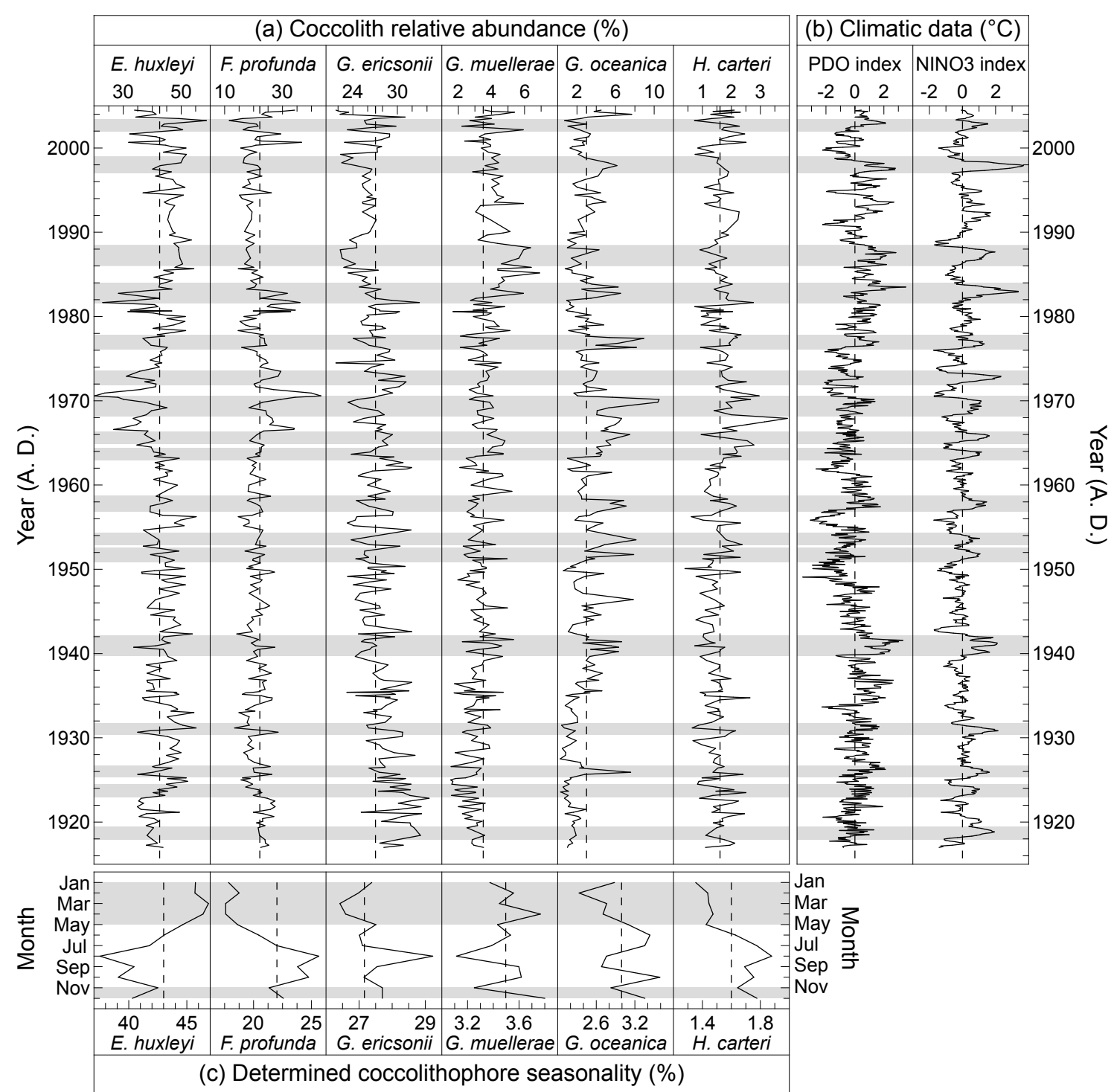

Fig. 3. (a) Relative abundances of six selected coccolithophore species in core B from multicore 1MC-3, cruise BASIN 2004. (b) PDO index (Mantua et al., 1997; Zhang et al., 1997) (data available at http://jisao.washington.edu/pdo/PDO.latest) and extended NINO3 index (Kaplan et al., 1998; Reynolds et al., 2002). (c) Reconstructed seasonality for the six selected coccolithophores species determined from the ultra-high resolution record of core $\mathrm{B}$.

highest relative abundance of $F$. profunda to the warmest SST recorded by instrumental data of that year. These periods of high SST correspond roughly to mid summer and early fall. Results on the SBB abundance of $F$. profunda obtained by Haidar and Thierstein (2001) seem to corroborate our results. The final age model for core B remains in agreement with the age model of core A (Fig. 2d). This final age model provides a mean varve thickness of $2.9 \mathrm{~mm}$ (standard deviation: $1.3 \mathrm{~mm}$ ) and allows us to describe time-series of coccoliths' relative abundances with high resolution from 1917 to 2004 (Fig. 3a), with a subannual mean resolution.

\subsection{Coccolith weight estimate}

It is possible to estimate the amount of coccolith calcite in a sample by weighing the $<27 \mu \mathrm{m}$ fraction (Broerse, 2000), but this semi-quantitative method relies on the assumption that the entire $<27 \mu \mathrm{m}$ fraction consists of coccolith calcite. This study uses images produced by SYRACO to estimate the individual weight of coccoliths (Beaufort, 2005) belonging to the order Isochrysidales (i.e., E. huxleyi, G. ericsonii, G. muellerae, and G. oceanica). The method relies on the brightness of calcitic grains when viewed in cross-polarized light. Brightness and color of an object in crosspolarized light depend on (i) the object's thickness in a range of 0 to 

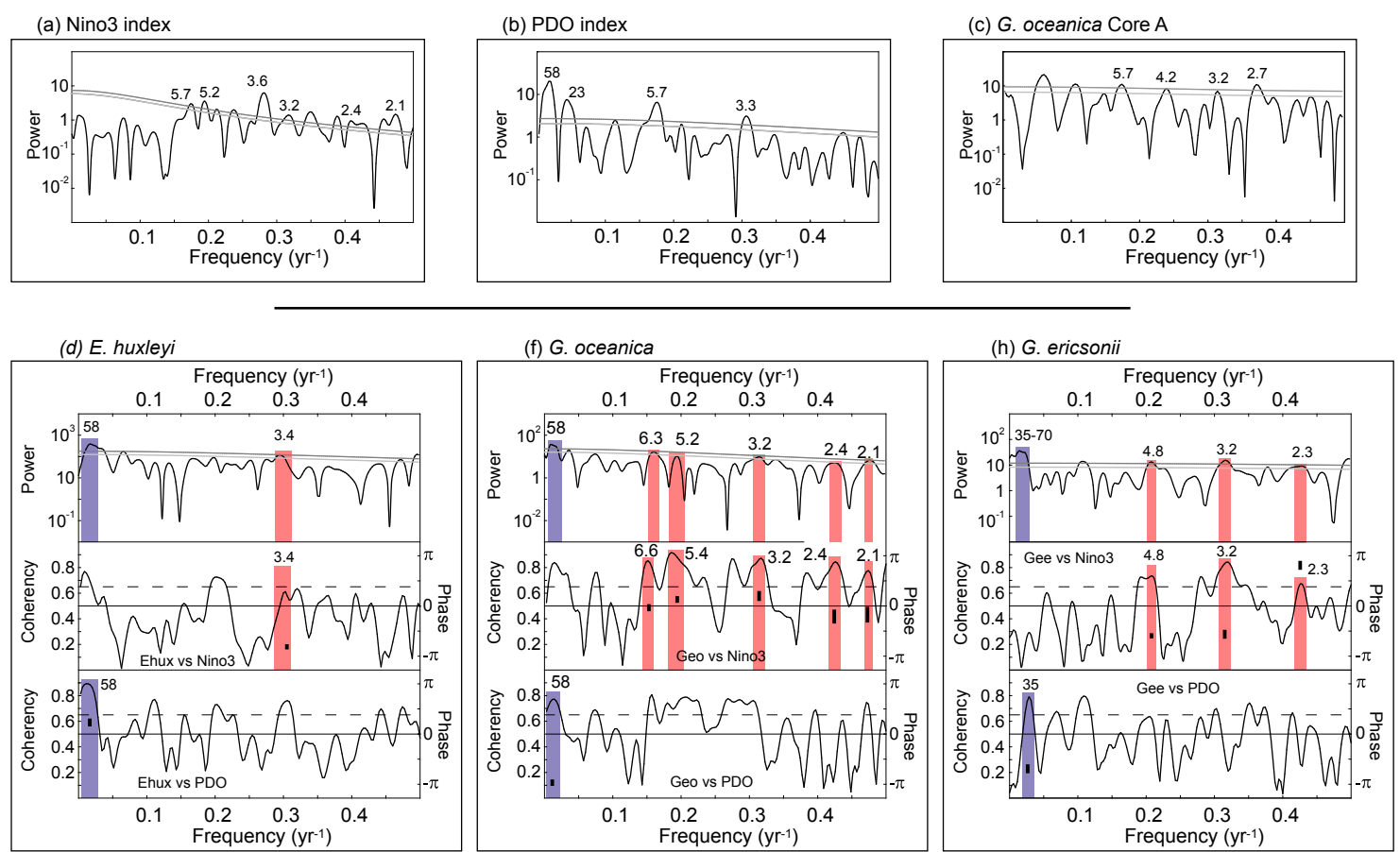

(e) F. profunda

(g) H. carteri
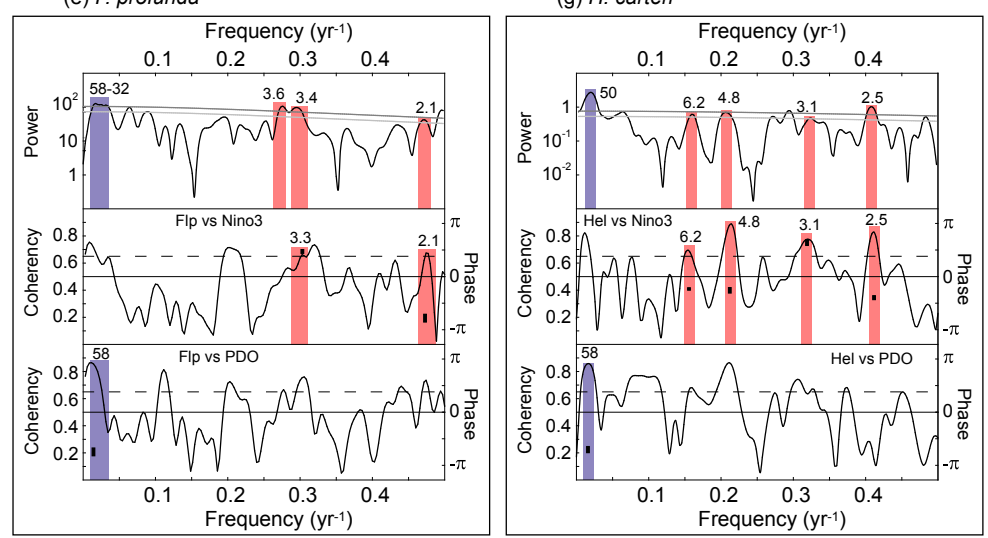

(i) G. muellerae

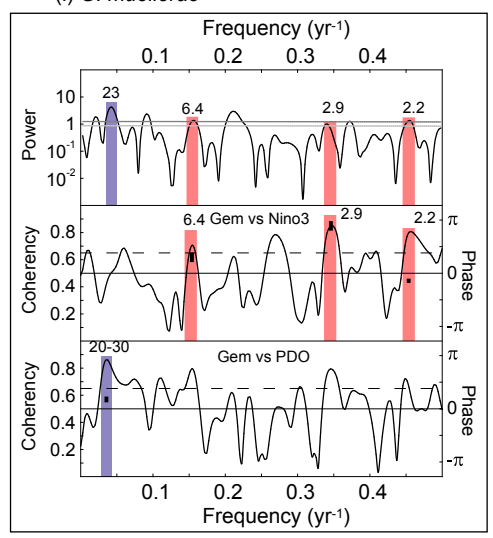

Fig. 4. Spectral analyses of the extended NINO3 index (a), PDO index (b) and \% G. oceanica in core A (c) (light grey lines denote $80 \%$ confidence intervals; dark grey line denote $90 \%$ confidence intervals). (d) From top to bottom: Spectral analysis of \% E. huxleyi (light grey line denotes $80 \%$ confidence interval; dark grey line denotes $90 \%$ confidence interval); cross-spectral analysis between \% E. huxleyi and extended NINO3 index (coherency between spectra is denoted by black line; phase is indicated by black rectangles); cross-spectral analysis between \% of E. huxleyi and PDO index (coherency between spectra is denoted by black line; phase is indicated by black rectangles). Here the coherency is significant at $90 \%$ over 0.672 (dashed line). Red bars represent significant frequencies in ENSO band common to \% of E. huxleyi and extended NINO3 index. Blue bars represent significant frequencies in PDO band common to \% of $E$. huxleyi and PDO. The same comments and settings apply to other panels pertaining to other species: (e) F. profunda; (f) G. oceanica; (g) H. carteri; (h) G. ericsonii; (i) G. muellerae.

$1.5 \mu \mathrm{m}$, (ii) its orientation, and (iii) its birefringence index, therefore making it common practice for nannopaleontologists to associate coccolith thickness with brightness. We converted the brightness of individual coccoliths into a number of pixels that was fed into a calibrated transfer function to indicate the amount of calcite (Beaufort, 2005).

\subsection{Spectral analyses}

We performed spectral analyses on the extended NINO3 index (Kaplan et al., 1998; Reynolds et al., 2002) (Fig. 4a), on the PDO index (Mantua et al., 1997; Zhang et al., 1997) (Fig. 4b), on the relative abundances of G. oceanica of core A (Fig. 4c) and on the relative abundances of six species (Fig. 4d-i). Redfit software (Schulz and Mudelsee, 2002) 
generated power spectra and associated $80 \%$ and $90 \%$ confidence intervals from our unevenly spaced data (Fig. 4). The resulting spectral coccolith data were then compared to those of the extended NINO3 and PDO indices by performing cross-spectral analyses. We used cross-spectral BlackmanTukey methods in the Analyserie package (Paillard et al., 1996). The resulting coherency between cross-spectra is significant within a $90 \%$ confidence interval over a value of 0.672 (Fig. 4d-i).

\section{Results}

\subsection{Relative abundances of coccolith species}

At least $96 \%$ of the SBB sedimentary coccolith assemblage is composed of E. huxleyi, F. profunda, G. ericsonii, G. muellerae, G. oceanica, and H. carteri. Other species present in SBB sediments, such as Calcidiscus leptoporus, Coccolithus pelagicus and Umbilicosphaera sibogae (De Bernardi et al., 2005) express insufficient relative abundances for the purpose of this study. Emiliania huxleyi, G. ericsonii and $F$. profunda dominate the SBB coccolithophore assemblages and jointly account for almost $85-90 \%$ of all coccoliths (Fig. 3a), whereas G. muellerae, G. oceanica and H. carteri jointly represent only $8-10 \%$ of the assemblages (the six species are listed in decreasing order of relative abundance; Fig. 3a).

Counts of E. huxleyi may include small placoliths of the genus Reticulofenestra and Gephyrocapsa that are not distinguished by automatic image analysis. However, comparative scanning electron microscopy (SEM) counts indicate that the resulting error is limited to a few \% (Grelaud et al., 2009). Emiliania huxleyi's relative abundance of $\sim 40 \%$ is dominating for the entire period covered in this study, with the exception of short episodes in 1966, 1970, 1980-1982, 2000, and 2004 when $F$. profunda becomes most abundant (Fig. 3a). Gephyrocapsa ericsonii represents $\sim 27 \%$ of the assemblages and is the second most abundant species in SBB sediment (Fig. 3a), being present at a relatively stable level throughout the record, with a slightly decreasing trend toward 2004. Florisphaera profunda is the third most abundant species representing $21 \%$ of the assemblages (Fig. 3a). Its relative abundance is stable from 1917 to $\sim 1965$, but exhibits occasional large peaks between $\sim 1965$ and 2004 . Only $3.5 \%$ of the assemblages are contributed by G. muellerae, with an overall increasing trend from $\sim 1917$ to 2004 . The relative abundances of $G$. oceanica are highly variable and account for 0.25 to $10.5 \%$ with a mean of $3 \%$ (Fig. 3a). Out of the six species counted, the lowest relative abundances from 0.4 to $3.9 \%$ are contributed by $H$. carteri, with a mean value of $1.6 \%$. The abundances of these two last species are enhanced during strong El Niño events such as in 1982-1983 and 1997-1998 (Fig. 3a).

\subsection{Seasonality of coccolithophores inferred from varved SBB sediment}

We evaluated the seasonality of the six selected coccolithophore species in core B by averaging each species' relative abundances for each season of each year during the period 1917-2004. The calculated decimals of the age model for each year are then used to evaluate the season. For example, 1917-1917.25 corresponds to winter 1917 (January to March), 1917.25-1917.5 corresponds to spring (April to June), 1917.5-1917.75 corresponds to summer (July to September) and 1917.75-1918 corresponds to fall (October to December). According to this definition, the four species F. profunda, G. ericsonii, G. oceanica, and H. carteri preferentially thrive during summer and fall (Fig. 3c), while $E$. huxleyi and G. muellerae bloom preferentially during winter and spring (Fig. 3c).

\subsection{Spectral analyses}

Spectral analyses of the extended NINO3 and PDO indices (Fig. 4a-b) were compared to those of the relative abundances of the six selected species using cross-spectral analyses (Fig. $4 \mathrm{~d}-\mathrm{i}$ ). The three important ranges of frequencies are (i) the 2-7 yr pseudo-frequency of ENSO, (ii) the $20-30 \mathrm{yr}$ PDO band, and (iii) the 50-70 yr very low frequency of the pentadecadal band (Minobe, 2000). Frequencies commensurate with ENSO were expressed by the six species (Fig. 4di), PDO frequencies were found for G. muellerae and G. ericsonii (Fig. 4h-i), and spectral evidence for the pentadecadal band was found for E. huxleyi, F. profunda, G. oceanica, and H. carteri (Fig. 4d-g).

It seems natural that we observed frequencies in the $\mathrm{El}$ Niño band since we used the NINO3 index to construct the age model of core B. We assume that this correlation had no major influence on the spectral analyses results since (i) the age model of core $B$ is subject to the same uncertainty of the age model of core A (Fig. 2d) and (ii) the spectral analysis of the relative abundance of G. oceanica in core A exhibits significant frequencies in the El Niño band (Fig. 4c), suggesting that the signal had been present before the correlation between cores.

\subsection{Coccolith morphometry}

Our automatic image analysis system used a calibrated algorithm to estimate the size $(\mu \mathrm{m})$ and the weight in picogram (pg) of each recognized coccolith of the order Isochrysidales. Size corresponds to a coccolith's largest diameter. For each sample we determined mean values of size and weight for the three species E. huxleyi, G. muellerae, and G. oceanica (Fig. 5a). The observed mean sizes and standard deviations fluctuate around $2.74 \pm 0.04 \mu \mathrm{m}, 3.33 \pm 0.12 \mu \mathrm{m}$, and $3.96 \pm 0.13 \mu \mathrm{m}$, respectively, and are in agreement with observed sizes of coccolithophores (Young et al., 2003). 

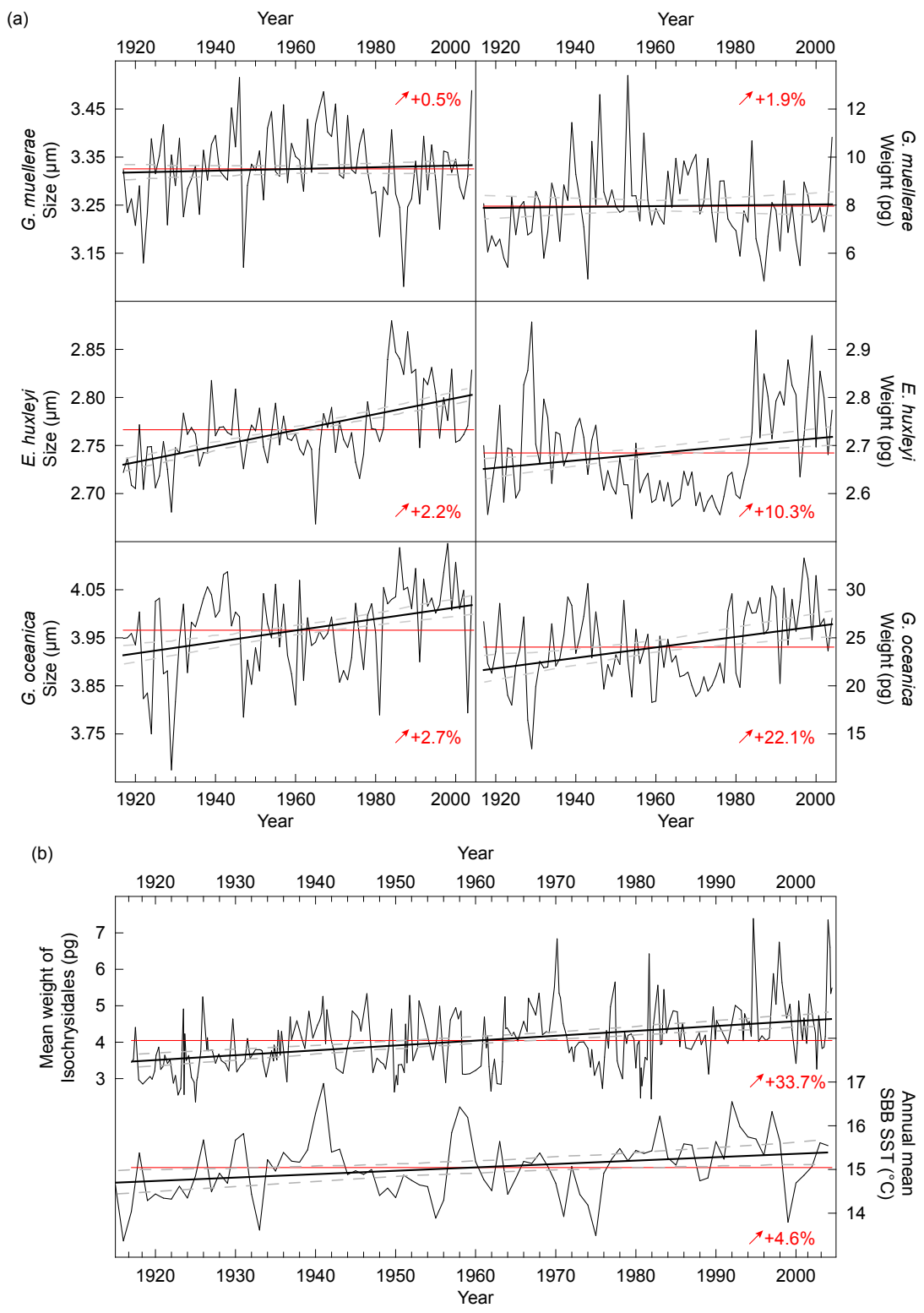

Fig. 5. (a) Annual mean coccolith size in $\mu \mathrm{m}$ (left part) and weight in pg (right part) of G. muellerae, E. huxleyi and G. oceanica (from top to bottom). (b) Mean weight of individual Isochrysidale coccoliths in pg and annual mean sea surface temperature of Santa Barbara Basin according to the reconstruction of global SST (Smith and Reynolds, 2003), and derived from the version of COADS release 2 (Woodruff et al., 1998), based on combined satellite and in situ instrumental data (Reynolds et al., 2002). SST data are extracted from the IRI/LDEO Climate Data Library (http://iridl.ldeo.columbia.edu/). Red line represents the mean value of each series; thick black line corresponds to linear regression and indicates the general tendency of each parameter from AD $\sim 1917$ to 2004, black dashed lines correspond to the interval of confidence at $95 \%$. Red arrows and associated numbers correspond to the $\%$ increase of each parameter between $\sim 1917$ and 2004 .

Mean weights fluctuate around $3.41 \pm 0.6 \mathrm{pg}, 7.96 \pm 1.9 \mathrm{pg}$, and $24.04 \pm 5.9 \mathrm{pg}$, respectively. Average contributions to Isochrysidales-produced calcite amount to $45 \%$ from $E$. huxleyi, $\sim 22 \%$ from G. oceanica, and $17.5 \%$ from G. muellerae. Size and weight of coccoliths tend to increase between $\sim 1917$ and 2004 by (i) $0.5 \%$ and $1.9 \%$ for G. muellerae, (ii) $2.2 \%$ and $10.3 \%$ for E. huxleyi, and (iii) $2.7 \%$ and $22.1 \%$ for $G$. oceanica, respectively (Fig. 5a). Increases seem to have accelerated from the 1970s to 2004 for E. huxleyi and G. oceanica (Fig. 5a). The mean weight of calcite of a coccolith belonging to the order Isochrysidales (i.e., the three species combined) increased from $\sim 1917$ until 2004 by more than 33\% (Fig. 5b). 


\section{Discussion}

\subsection{Coccolith ecology in SBB inferred from the sedi- ment record}

The SBB is hydrologically dominated by the California Current (CC) and the California Counter Current (CCC) (Hendershott and Winant, 1996). The equatorward cold CC enters the SBB from the west and supplies nutrients via injection of upwelled waters from off Point Arguello and Point Conception (Fig. 1). Seasonal differences in wind along the coast off Point Arguello limit strong upwelling mostly to summer and make upwelling more variable during winter (Dorman and Winant, 1995). The CC triggers a counterclockwise circulation inside the SBB (Fig. 1) with maximum strength between spring and fall (Hendershott and Winant, 1996). During winter, the CC carries colder and nutrientdepleted waters into the SBB, which are favorable for coccolithophore species like G. muellerae that prefers cold and moderately productive waters (Bollmann, 1997; Flores et al., 1997; Knappertsbusch et al., 1997). We observed high abundances of G. muellerae from November to April (Fig. 3c) prior summer strong upwelling and when SST is coldest in the SBB. The dynamics of the CC may also influence the abundance of $G$. ericsonii that thrives in high nutrient environments (Takahashi and Okada, 2000) between 13 and $22^{\circ} \mathrm{C}$ (Okada and McIntyre, 1979). We observed highest abundances of $G$. ericsonii during summer when upwelling off Point Arguello and Point Conception is active. During this period, the SST ranges from 14.5 to $17.5^{\circ} \mathrm{C}$ (mean SST values for the last century, calculated from the IRI/LDEO Climate Data Library; http://iridl.ldeo.columbia.edu) (Fig. 3c).

The CCC originates from further south, enters the SBB from the east, and continues flowing northward (McLain and Thomas, 1983). The relatively warm and salty waters of the CCC influence the SBB mostly from spring to fall and seem to be reduced during winter (Hendershott and Winant, 1996). The subtropical origin of the CCC favors warm coccolithophore species like G. oceanica and H. carteri. Gephyrocapsa oceanica is found largely in tropical and subtropical seas (Andruleit et al., 2003, 2000; McIntyre et al., 1970) and prefers high nutrient environments such as upwelling areas or continental shelves (Giraudeau, 1992; Houghton and Guptha, 1991; Mitchellinnes and Winter, 1987; Young, 1994). SST is the most important oceanographic parameter controlling the distribution of G. oceanica in the SBB (De Bernardi et al., 2005) triggering high abundances during the second half of spring, when SST rises during summer (Fig. 3c) and SBB surface waters are warm and rich in nutrients. The same pattern is observed for H. carteri (Fig. 3c), which thrives in warm waters (Brand, 1994; McIntyre and $\mathrm{Be}, 1967$ ) and shares ecological similarities with G. oceanica (Giraudeau, 1992). The CCC may also influence $F$. profunda which lives below the deep chlorophyll maximum in the lower photic zone in tropical to subtropical regions (Okada and Honjo, 1973). Florisphaera profunda's preference for stratified waters is well suited for the SBB during summer (De Bernardi et al., 2005) when its highest abundance is observed (Fig. 3c) and when the SBB is well stratified (Kincaid et al., 2000).

Emiliania huxleyi is the most abundant and ubiquitous coccolithophore in modern oceans. Its strains tolerate large ranges of salinity and temperature and allow it to inhabit both the Red Sea (high salinity) and the Black Sea (low salinity). Its ability to grow in eutrophic and oligotrophic waters testifies to this species' adaptation to a wide range of nutrient levels (Winter et al., 1994). The SBB sediment record indicates that $E$. huxleyi is still abundant during winter and early spring (Fig. 3c) when upwelling is absent or weak. Such behavior makes $E$. huxleyi an opportunistic species that is able to live in cold and well mixed waters with low levels of nutrients. The collective observations of this and earlier studies form the basis for dividing the six quantified species into three categories. (i) The CCC-controlled summer influence is best reflected by the response of $F$. profunda, G. ocean$i c a$, and $H$. carteri. (ii) The CC-controlled winter influence is witnessed by G. muellerae, and the CC-controlled summer influence is expressed by G. ericsonii. (iii) Emiliania huxleyi appears to be opportunistic and endemic to the SBB.

\subsection{Influence of ENSO and PDO on SBB coccol- ithophores}

The CC and the CCC are parts of the California Current system extending $1000 \mathrm{~km}$ from offshore Oregon to Baja California (Miller et al., 1999). The CC system is modulated across various time scales by (i) ENSO with a pseudofrequency of $\sim 2$ to $7-8 \mathrm{yr}$, (ii) the PDO with a bidecadaltridecadal frequency of $\sim 20$ to $30 \mathrm{yr}$, and (iii) by pentadecadal variability of $\sim 50$ to 75 years (Lluch-Belda et al., 2003; Minobe, 2000). Interannual temperature variability of SBB surface waters can be reduced to two opposite states that are expressed as warm and cold episodes. A warm phase is associated with a reduced CC and an intensification of the CCC. Warm phases tend to cause a northward migration of southern fauna (Lluch-Belda et al., 2003) and flora (e.g., diatoms; Thunell, 1998), including coccolithophores. The opposite occurs during a cold phase when the CC is strengthened while the CCC weakens. The driving forces behind this variability of the $\mathrm{CC}$ system have geographically different origins. The PDO and the pentadecadal oscillation modulate the CC system through the intensity and east-west position of the Aleutian Low (Miller and Schneider, 2000), whereas ENSO modulates the CC system through the intensity of the North Pacific High (Bograd and Lynn, 2001).

We performed spectral and cross-spectral analyses of our microfossil time-series from six species in combination with the extended NINO3 and PDO indices to evaluate the hydrographic variability on different time scales and to explore the impact on SBB's coccolithophore community (Fig. 4). 
All examined time-series exhibit frequencies in the 2 to $7-$ 8 yr ENSO band (Fig. 4d-i). The ENSO band can be divided into a sub-band of 2.5 to $3-4 \mathrm{yr}$ that is generally associated with the duration of El Niño events and the alternation to La Niña conditions, whereas the sub-band of 34 to $7-8 \mathrm{yr}$ relates more to the spacing between successive large El Niño events (Graham and White, 1988; Zebiak and Cane, 1987). The six coccolithophore time-series exhibit significant periodicities around 2.5 and 3-4 yr. Although this suggests that all species are influenced by ENSO, the relationship of each species with ENSO depends mostly on its ecology. Thus, high abundances of warm species $G$. ocean$i c a$ and $H$. carteri occur simultaneously with El Niño events as suggested by cross-spectral phases (Figs. $3 \mathrm{a}, 4 \mathrm{f}-\mathrm{g}$ ). This agrees with the observation that the CCC is enhanced during a warm event (Bograd and Lynn, 2001), allowing an extended northward advection of tropical species (Lluch-Belda et al., 2003) like G. oceanica and H. carteri. The same holds true for F. profunda (Figs. 3a, 4e) although high abundances of this species may be slightly lagging behind El Niño occurrences. To the contrary, the abundances of G. ericsonii and $G$. muellerae, which are associated with a strong $\mathrm{CC}$, are negatively correlated with warm events (Figs. 3a, 4h-i) when the CC in the SBB is temporarily weakened (Lluch-Belda et al., 2003). The same is true for the dominant species E. huxleyi (Figs. 3a, 4d), suggesting that this species prefers $\mathrm{CC}$ rather than $\mathrm{CCC}$ water.

Spectral results from E. huxleyi and F. profunda indicate no significant response to strong El Niño events in the lowfrequency ENSO sub-band of 3-4 to 7-8 yr (Fig. 4d-e). However, all four other species exhibit significant periodicities between 3 and 7 years (Fig. 4f-i), reflecting an enhancement of their response patterns described above for normal El Niño/La Niña cycles. Cross-spectral phases confirm that $G$. oceanica and H. carteri are associated with warm water events, whereas G. ericsonii and G. muellerae prefer cold waters.

Cross-spectral analyses of the PDO index and the six microfossil time-series show that only the CC-associated species G. ericsonii and G. muellerae exhibit 20 to $30 \mathrm{yr}$ periodicities corresponding to the PDO (Fig. 4h-i). Crossspectral phases associate the PDO's cool phase with high abundances of G. ericsonii, and the PDO's warm phase with high abundances of G. muellerae. This pattern agrees with ecological observations of these two species in the California Borderland (Chavez et al., 2003) where low nutrient availability during warm phases favors $G$. muellerae which is associated to moderately productive waters. During cool phases, the region is characterized by higher nutrient availability favoring G. ericsonii. It seems that only species growing under the influence of the CC are affected by the PDO, suggesting an 'equatorward' expression of PDO variability in the SBB.

The spectral patterns of time-series from the four other species witness responses to a $50-58 \mathrm{yr}$ component of pen- tadecadal variability (Fig. 4f-i). The same component is observed in the power spectra of the PDO (Fig. 4b). However, our $87 \mathrm{yr}$ long record from AD 1917 until 2004 does not cover two successive cycles and is thus too short to lend statistical weight to this observation.

\subsection{0th century warming and increasing mass of coc- coliths}

Many studies have shown that 20th century warming affected the food chain at all trophic levels in the northeastern Pacific and particularly in the CC system, extending from marine algae (Tegner et al., 1996) to zooplankton (Brinton and Townsend, 2003; Roemmich and McGowan, 1995) and fish (Mantua et al., 1997). Since the 1950s mean SSTs in some places off Southern California have increased by almost $1.5^{\circ} \mathrm{C}$ and caused an $80 \%$ reduction of macrozooplanktic biomass (Roemmich and McGowan, 1995). Regional abundances of tropical foraminifera species increased at the expense of temperate species (Field et al., 2006). However, we did not identify any increase of the relative abundances of tropical coccolithophore species in SBB between $\sim 1917$ and 2004, especially during the last 30 years (Fig. 3a). The reverse is true for the cold species G. muellerae which did not exhibit a decrease of its relative abundances during the same period (Fig. 3a).

Coccolith assemblages are largely influenced by seasonality and El Niño. SST exhibits amplitude of $\sim 4^{\circ} \mathrm{C}$ during a normal year (mean SST amplitude throughout the year for the last century, calculated from the IRI/LDEO Climate Data Library; http://iridl.ldeo.columbia.edu) and a positive SST anomaly of $\sim 3^{\circ} \mathrm{C}$ during an El Niño peak in winter (IRI/LDEO Climate Data Library; http://iridl.ldeo.columbia. edu). The regional warming since the 1950 s is maximally $1.5^{\circ} \mathrm{C}$ (Roemmich and McGowan, 1995). This long term SST increase is small in comparison to seasonal or El Niñoinduced SST amplitudes and therefore is not clearly recorded in the relative abundance patterns of coccoliths. Even if relative abundances of some coccolithophores are sensitive enough to capture seasonal to decadal SBB regional oceanographic variability and trends, the approach may fail for monitoring global marine changes such as long term variability of nutrient availability, SST warming or ocean acidification linked to anthropogenic $\mathrm{CO}_{2}$ release.

In order to address long term oceanographic changes, which are not recorded by relative abundances of coccoliths, we investigated morphometric parameters of the CC-associated species G. muellerae, the CCC-associated $G$. oceanica, and the SBB endemic species E. huxleyi. The average weight and size of each of the three species increased during the last century, although the rates of increase differed among the three species (Fig. 5). Increases in weight and size are largest for G. oceanica and E. huxleyi and smaller for G. muellerae (Fig. 5a), suggesting that SBB coccolithophore carbonate mass experienced enhancement in waters of the 
CCC between $\sim 1917$ and 2004, whereas carbonate mass changed little in waters deriving from the $\mathrm{CC}$. After merging the data of the three species, a $>33 \%$ increase in mean coccolith weight was determined for the order Isochrysidales over 87 years from $\sim 1917$ until 2004 (Fig. 5b).

A possible explanation for this increase is that older calcareous fossils in the deeper part of the core could have undergone slow dissolution. Increases in weight and size over time would thus be an artifact linked to better preservation of younger coccoliths. However, Beaufort et al. (2007) dissolved $80 \%$ of coccoliths during experimental acid leaching and observed that, the weight of remaining coccoliths had not changed significantly. The authors concluded that the weight of sedimentary coccoliths is roughly corresponding to the weight of the original coccoliths because the dissolution breaks coccoliths into unrecognizable fragments rather than decreasing progressively their volume. Hence, the coccoliths remaining after dissolution keep their primary mass. Moreover, scanning electron microscopic (SEM) examination of samples from the top and the bottom of core B indicates an absence of coccolith dissolution. The observed increase in size and weight of coccoliths in the SBB corresponds to a primary signal and potentially reflects the regional emergence of heavier calcified coccolithophores.

Alternate explanations are based on long term changes in the availability of nutrients such as dissolved iron and phosphate. It has been suggested that coccolithophores secrete highly calcified coccoliths in environments with higher nutrient abundances such as in upwelling areas (Beaufort et al., 2008 , 2007) or fertilizing experiment in mesocosm (Engel et al., 2005). The 20th century increase in coccolithophores' carbonate mass would then reflect an increase in nutrient availability in the SBB. However, the California Current System (CCS) has experienced a spin-down since the beginning of the 20th century implying a deeper thermocline and upwelling of warm, nutrient-poor waters (Weinheimer and Cayan, 1997). This could be responsible for the observed marked decrease in zooplankton biomass in the California bight since the 1950s (Roemmich and McGowan, 1995) and would suggest reduced primary production. This scenario argues against a connection of increased carbonate mass of coccolithophores with nutrient availability in the SBB.

The availability of iron exerts the ultimate control over the size of the phytoplankton community in the Northeastern Pacific (Boyd et al., 1996). This is particularly true for the CCS since an abundant iron is known to enhance productivity (Bruland et al., 2001; Hutchins et al., 1998). It appears that iron limitation leads to a decrease of coccolithophores' cell growth rate and presumably to a limitation of calcite formation (Schulz et al., 2007). An increase in dissolved iron concentration in the CCS may thus lead to an increase in calcite precipitation by coccolithophores. However, the primary source of iron in the CCS derives from resuspended sedimentary particles in the benthic boundary layer, followed by upwelling of this iron-rich water, rather than by direct river- ine input (Johnson et al., 1999; Bruland et al., 2001). As 20th century spin-down deepened the thermocline and limited upwelling, we suppose that the concentration of dissolved iron decreased during the same period and prevented an increase in coccolithophore populations and coccolith mass.

The growth of coccolithophores is also influenced by the availability of phosphorus. Low to moderate phosphate concentrations may produce large blooms of E. huxleyi (reviewed by Zondervan, 2007), but the effect of phosphorus on the calcite production by E. huxleyi continues to be debated. For example, culturing experiments in seawater enclosures indicate that low to moderate phosphate concentrations can produce intensive blooms of E. huxleyi, albeit with comparatively low rates of particulate inorganic carbon precipitation by E. huxleyi cells. In contrast, higher phosphate concentrations produce limited blooms with relatively higher rates of particulate inorganic carbon precipitation by E. huxleyi (van Bleijswijk et al., 1994). In other words, there is a decoupling between the rate of production of $E$. huxleyi cells and the rate of precipitation of particulate inorganic carbon by these cells at certain phosphate concentrations. Low to moderate phosphate concentrations can produce extensive blooms with thin coccoliths, whereas high phosphate concentrations produce limited blooms with heavier coccoliths.

On the other hand, the opposite situations have been observed with enhanced calcite production by E. huxleyi at low phosphate concentrations and reduced calcite production at high phosphate concentrations (e.g. Müller et al., 2008; Paasche, 1998). Low concentrations of phosphorus let cells grow normally during the G1 assimilation phase (Müller et al., 2008), which precedes DNA replication (S phase) and cell division (G2 phase; Paasche, 2002). Calcification presumably occurs during the G1 phase (Van Emburg, 1989) and will likely be enhanced with increasing duration of G1. At higher phosphorus concentrations, faster cell growth limits calcification during a shortened G1 phase and prematurely triggers S and G2 phases independently of the degree of calcification (Müller et al., 2008), thus explaining why coccoliths are less calcified when phosphorus availability is high.

Along the North American Pacific margin, the oxygendepleted bottom waters enhance phosphate regeneration from sediments and provide a positive feedback on productivity (Ingall and Jahnke, 1994). Similar to the case outlined above for iron, a spin-down of the CCS would lead to decreased phosphate availability. In this case, the production of E. huxleyi, and presumably also the production of the overall coccolithophore assemblages, could have been enhanced during slightly lowered phosphate availability (Zondervan, 2007). It is difficult to unambiguously demonstrate that phosphorus is responsible for the observed Isochrysidales coccoliths' mass increase during the 20th century. Nevertheless, Müller et al.'s (2008) evidence for the role of phosphorus in the cell growth cycle of $E$. huxleyi supports our hypothesis that phosphate availability partly explains the observed increase of coccolith mass. 
In addition to CCS spin-down and reduced productivity, the SBB has experienced a mean regional SST warming of $\sim 0.7^{\circ} \mathrm{C}$ concomitant with the increase in size and weight of Isochrysidales coccoliths (Fig. 5b). These results are in agreement with those obtained in the Bay of Biscay, where heavily calcified coccoliths occurred during summer when SST is highest (Beaufort and Heussner, 2001). Moreover, latitudinal variations in SST are responsible for the distribution of different morphological groups of the genus Gephyrocapsa in the Holocene world ocean (Bollmann, 1997), whereby the largest coccoliths of genus Gephyrocapsa are found in warm equatorial oceans, while smaller specimens are found at higher latitudes in cooler waters. Similar observations were reached by Beaufort et al. (2008): although temperature was one among several other covarying parameters, they demonstrated that size and weight of coccolithophore species E. huxleyi and G. oceanica were larger in warmer surface waters from the southeastern Pacific Ocean in the Marquesas archipelago, and became smaller in the cooler surface waters of the Peru-Chile upwelling region. The observation of increasing calcite mass of E. huxleyi and $G$. oceanica could be interpreted as a result of a warming of the SBB. Between the 1940s and the 1970s, carbonate weights of E. huxleyi and G. oceanica decreased (Fig. 5a). This period corresponds to the cool phase of the PDO, which implies cooler SST along the North American Pacific margin. This aspect supports our hypothesis that warm SST enhances Isochrysidales' carbonate mass. It may be possible that high frequency variability in carbonate weight of E. huxleyi and $G$. oceanica during the 20th century is linked to El Niño variability, with an increase in carbonate mass during warm episodes. Those temperature changes are also concomitant to change in the strength of North American margin upwelling (Feely et al., 2008) which carries high $\mathrm{CO}_{2}$, low carbonated waters into the SBB. We also have to take into account the possibility that a change in carbonate chemistry would affect the calcite mass of coccolithophores.

The last century has witnessed an increasing net influx of atmospheric carbon dioxide into the world's oceans, a rising $p \mathrm{CO}_{2}$ of surface waters, and under-saturation with respect to aragonite, especially along the North American Pacific margin (Feely et al., 2008). Even if this area is clearly a source of $\mathrm{CO}_{2}$, it continues to accumulate more anthropogenic $\mathrm{CO}_{2}$. The ability of SBB's coccolithophores to produce calcitic shells may be affected by acidification of surface waters overlying the Pacific North American continental shelf. Such conditions are expected to result in reduced coccolithophore carbonate mass and a concomitant decrease in size and weight of coccoliths, as previously suggested in laboratory studies on coccolithophore calcification rate (i.e. the mass of $\mathrm{CaCO}_{3}$ precipitated per time unit) (Riebesell et al., 2000; Sciandra et al., 2003; Zondervan et al., 2001) and under conditions of artificially increased $p \mathrm{CO}_{2}$ in ocean waters (Delille et al., 2005).
These studies controlled $p \mathrm{CO}_{2}$ by adjusting $\mathrm{pH}$ (Riebesell et al., 2000; Zondervan et al., 2001) or by purging with $\mathrm{CO}_{2}$-free, ambient, or $\mathrm{CO}_{2}$-enriched air (Delille et al., 2005; Sciandra et al., 2003) and jointly arrived at the conclusion that coccolithophore calcification is reduced under elevated $p \mathrm{CO}_{2}$ conditions in seawater. In contrast, IglesiasRodriguez et al. (2008) cultured E. huxleyi under conditions of increasing $p \mathrm{CO}_{2}$ by bubbling $\mathrm{CO}_{2}$ in batch incubation experiments and demonstrated that increasing $p \mathrm{CO}_{2}$ in seawater was compatible with an increase in coccolith weight. A controlled decrease in $\mathrm{pH}$ by adding acid changed the balance of individual dissolved inorganic carbon (DIC) chemical species but did not change the total DIC concentration. In contrast, the lowering of $\mathrm{pH}$ by $\mathrm{CO}_{2}$ injection (Riebesell et al., 2000; Zondervan et al., 2001) enhances the production of bicarbonate $\mathrm{HCO}_{3}^{-}$, which is the chemical DIC species used for the production of calcite in coccolithophores (Anning et al., 1996; Buitenhuis et al., 1999). The results from the laboratory culture experiments of Iglesias-Rodriguez et al. (2008) are corroborated by observations of a $40 \%$ increase in average coccolith weight across the last 220 years, as recorded in a box core from the subpolar North Atlantic (Iglesias-Rodriguez et al., 2008). The increases also compare well with our observed increase of $>33 \%$ in mean weight of SBB Isochrysidales coccoliths. A continued future increase in $p \mathrm{CO}_{2}$ of surface waters in the $\mathrm{SBB}$, and by extension along the entire North American Pacific margin, would potentially increase the weight and size of microfossils from E. huxleyi and G. oceanica, but would exclude G. muellerae which seems to be unable to take advantage of increased $p \mathrm{CO}_{2}$. It may be possible that the contrasting response of $G$. muellerae's carbonate mass to increased $p \mathrm{CO}_{2}$ is based on physiological or biochemical differences, and that $G$. muellerae shares characteristics with the subpolar species Coccolithus pelagicus, which has shown a negligible response to increased $p \mathrm{CO}_{2}$ (Langer et al., 2006).

The available evidence is still insufficient to unambiguously differentiate the influence of SST on coccolithophore carbonate mass from that of other sea surface water chemical properties such as $p \mathrm{CO}_{2},\left[\mathrm{HCO}_{3}^{-}\right]$, or alkalinity. In any case, our data suggest a link between modern oceanographic changes in SBB surface water properties and increased mass of coccoliths.

\section{Conclusions}

1) Automatic image analysis via SYRACO software quantified relative abundances of coccoliths along two sediment cores from a Santa Barbara Basin 2004 multicore and yielded reproducible and robust micropaleontological AD 1917-2004 time-series from six selected coccolithophore species.

2) Core $B$ allowed ultra-high sampling resolution and the reconstruction of seasonality of six coccolithophore 
species. Reconstructed seasonalities are in agreement with known climatic and surface hydrographic preferences of species in the modern Santa Barbara Basin.

3) Warm species thrive in summer when the northerly flowing California Counter Current warms the basin. The cold species Gephyrocapsa muellerae is preferentially found during winter when sea surface waters are coldest and low in nutrients. Gephyrocapsa ericsonii depends on high concentrations of nutrients and is found in summer when upwelling occurs off Point Conception. Emiliania huxleyi is opportunistic, ubiquitous, and able to live in cold and well mixed, nutrient-poor waters, primarily during winter.

4) The abundances of warm water species are enhanced during strong El Niño events, such as in 1982-1983 or 1997-1998.

5) Spectral analyses show that four out of six species respond to ENSO and PDO. High abundances of warm species Gephyrocapsa oceanica and Helicosphaera carteri are associated with El Niño. Gephyrocapsa muellerae and Gephyrocapsa ericsonii respond well to La Niña. Only two warm species are spectrally linked to the low frequency band of ENSO characterizing the time between successive strong El Niño events, e.g. between the events of 1982-1983, 1986-1987, 1991-1992 and 1997-1998. Relative abundances of Gephyrocapsa oceanica and Helicosphaera carteri can serve as paleoEl Niño indicators in Santa Barbara Basin.

6) Only two species respond spectrally to the PDO, namely Gephyrocapsa ericsonii being associated with the PDO cold phase (high nutrient availability) and Gephyrocapsa muellerae with the PDO warm phase (low nutrient availability). Relative abundances of Gephyrocapsa muellerae and Gephyrocapsa ericsonii are useful paleoPDO indicators in Santa Barbara Basin.

7) Emiliania huxleyi and Florisphaera profunda are apparently unaffected by PDO but seem to respond to the classical El Niño/La Niña alternation.

8) Examination of the morphometry of three species showed that the carbonate mass of coccoliths in the Santa Barbara Basin increased from AD 1917 until 2004. This increase of coccoliths' calcite mass occurred in the context of decreasing iron and phosphate nutrient availability and increasing SST and $p \mathrm{CO}_{2}$ of surface waters linked to anthropogenic release of $\mathrm{CO}_{2}$. It is difficult to discern which parameter mainly controls the observed increase of coccoliths' mass. The fact that iron was not responsible for coccoliths' mass increase increases the likelihood that phosphate availability, $p \mathrm{CO}_{2}$ and SST were key controls on coccolithophores' calcite precipitation. Further studies are needed to elucidate whether calcareous phytoplankton is able to take advantage of increasing $\mathrm{CO}_{2}$ greenhouse gas concentrations and associated SST warming.

Acknowledgements. We thank Noëlle Buchet for her technical assistance. Funds for this study were provided by the French Agence Nationale de la Recherche program award number ANR05 PICC. A. Schimmelmann acknowledges funding from NSF grant \#OCE-0752068.

Edited by: F. Joos

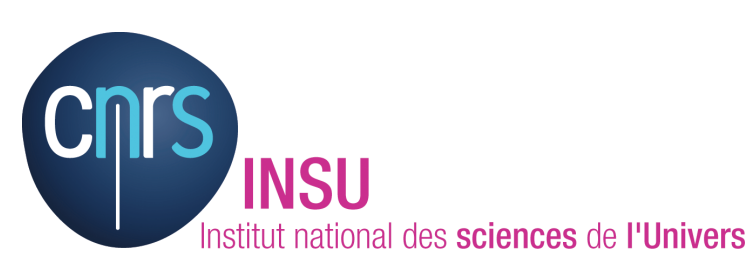

The publication of this article is financed by CNRS-INSU.

\section{References}

Andruleit, H., Stager, S., Rogalla, U., and Cepek, P.: Living coccolithophores in the northern Arabian Sea: ecological tolerances and environmental control, Mar. Micropaleontol., 49, 157-181, 2003.

Andruleit, H. A. and Baumann, K. H.: History of the Last Deglaciation and Holocene in the Nordic seas as revealed by coccolithophore assemblages, Mar. Micropaleontol., 35, 179-201, 1998.

Andruleit, H. A., von Rad, U., Bruns, A., and Ittekkot, V.: Coccolithophore fluxes from sediment traps in the northeastern Arabian Sea off Pakistan, Mar. Micropaleontol., 38, 285-308, 2000.

Anning, T., Nimer, N., Merrett, M. J., and Brownlee, C.: Costs and benefits of calcification in coccolithophorids, J. Marine Syst., 9, 45-56, 1996.

Beaufort, L., Lancelot, Y., Camberlin, P., Cayre, O., Vincent, E., Bassinot, F., and Labeyrie, L.: Insolation cycles as a major control equatorial Indian Ocean primary production, Science, 278, 1451-1454, 1997.

Beaufort, L. and Heussner, S.: Coccolithophorids on the continental slope of the Bay of Biscay - production, transport and contribution to mass fluxes, Deep-Sea Res. Pt. II, 46, 2147-2174, 1999.

Beaufort, L. and Heussner, S.: Seasonal dynamics of calcareous nannoplankton on a West European continental margin: the Bay of Biscay, Mar. Micropaleontol., 43, 27-55, 2001.

Beaufort, L., and Dollfus, D.: Automatic recognition of coccoliths by dynamical neural networks, Mar. Micropaleontol., 51, 57-73, 2004.

Beaufort, L.: Weight estimates of coccoliths using the optical properties (birefringence) of calcite, Micropaleontology, 51, 289297, 2005.

Beaufort, L., Probert, I., and Buchet, N.: Effects of acidification and primary production on coccolith weight: Implications for carbonate transfer from the surface to the deep ocean, Geochem. Geophy. Geosy., 8, Q08011, doi:10.1029/2006GC001493, 2007. 
Beaufort, L., Couapel, M., Buchet, N., Claustre, H., and Goyet, C.: Calcite production by coccolithophores in the south east Pacific Ocean, Biogeosciences, 5, 1101-1117, 2008, http://www.biogeosciences.net/5/1101/2008/.

Bograd, S. J. and Lynn, R. J.: Physical-biological coupling in the California Current during the 1997-99 El Niño-La Niña cycle, Geophys. Res. Lett., 28, 275-278, 2001.

Bollmann, J.: Morphology and biogeography of Gephyrocapsa coccoliths in Holocene sediments, Mar. Micropaleontol., 29, 319350, 1997.

Boyd, P. W., Muggli, D. L., Varela, D. E., Goldblatt, R. H., Chretien, R., Orians, K. J., and Harrison, P. J.: In vitro iron enrichment experiments in the NE subarctic Pacific, Mar. Ecol.-Prog. Ser., 136, 179-193, doi:10.3354/meps 136179, 1996.

Brand, L. E.: Physiological ecology of marine coccolithophores, in: Coccolithophores, edited by: Siesser, A. W. a. W. G., Cambridge University Press, Cambridge, 39-49, 1994.

Brinton, E. and Townsend, A.: Decadal variability in abundances of the dominant euphausiid species in southern sectors of the California Current, Deep-Sea Res. Pt. II, 50, 2449-2472, 2003.

Broerse, A.: Coccolithophore export production in selected ocean environments: seasonality, biogeography, carbonate production, Vrije Universiteit, Amsterdam, 185 pp., 2000.

Bruland, K. W., Rue, E. L., and Smith, G. J.: Iron and macronutrients in California coastal upwelling regimes: Implications for diatom blooms, Limnol. Oceanogr., 46, 1661-1674, 2001.

Buitenhuis, E. T., de Baar, H. J. W., and Veldhuis, M. J. W.: Photosynthesis and calcification by Emiliania huxleyi (Prymnesiophyceae) as a function of inorganic carbon species, J. Phycol., 35, 949-959, 1999.

Chavez, F. P., Ryan, J., Lluch-Cota, S. E., and Niquen, M.: From anchovies to sardines and back: Multidecadal change in the Pacific Ocean, Science, 299, 217-221, 2003.

D’Arrigo, R., Cook, E. R., Wilson, R. J., Allan, R., and Mann, M. E.: On the variability of ENSO over the past six centuries, Geophys. Res. Lett., 32, L03711, doi:10.1029/2004GL022055, 2005.

De Bernardi, B., Ziveri, P., Erba, E., and Thunell, R. C.: Coccolithophore export production during the 1997-1998 El Niño event in Santa Barbara Basin (California), Mar. Micropaleontol., 55, 107-125, 2005.

De Bernardi, B., Ziveri, P., Erba, E., and Thunell, R. C.: Calcareous phytoplankton response to the half century of interannual climatic variability in Santa Barbara Basin (California), Paleoceanography, 23, PA2215, doi:10.1029/2007PA001503, 2008.

Delille, B., Harlay, J., Zondervan, I., Jacquet, S., Chou, L., Wollast, R., Bellerby, R. G. J., Frankignoulle, M., Borges, A. V., Riebesell, U., and Gattuso, J. P.: Response of primary production and calcification to changes of $p \mathrm{CO}_{2}$ during experimental blooms of the coccolithophorid Emiliania huxleyi, Global Biogeochem. Cy., 19, GB2023, doi:10.1029/2004GB002318, 2005.

Dollfus, D. and Beaufort, L.: Fat neural network for recognition of position-normalised objects, Neural Networks, 12, 553-560, 1999.

Dorman, C. E. and Winant, C. D.: Buoy observations of the atmosphere along the west-coast of the United-State, 1981-1990, J. Geophys. Res.-Oceans, 100, 16029-16044, 1995.

Engel, A., Zondervan, I., Aerts, K., Beaufort, L., Benthien, A., Chou, L., Delille, B., Gattuso, J. P., Harlay, J., Heemann, C., Hoffmann, L., Jacquet, S., Nejstgaard, J., Pizay, M. D., Rochelle-
Newall, E., Schneider, U., Terbrueggen, A., and Riebesell, U.: Testing the direct effect of $\mathrm{CO} 2$ concentration on a bloom of the coccolithophorid Emiliania huxleyi in mesocosm experiments, Limnol. Oceanogr., 50, 493-507, 2005.

Feely, R. A., Sabine, C. L., Hernandez-Ayon, J. M., Ianson, D., and Hales, B.: Evidence for upwelling of corrosive "acidified" water onto the continental shelf, Science, 320, 1490-1492, doi:10.1126/science.1155676, 2008.

Field, D. B., Baumgartner, T. R., Charles, C. D., Ferreira-Bartrina, V., and Ohman, M. D.: Planktonic foraminifera of the California Current reflect 20th-century warming, Science, 311, 63-66, 2006.

Flores, J. A., Sierro, F. J., Francés, G., Vázquez, A., and Zamarreño, I.: The last 100,000 years in the western Mediterranean: sea surface water and frontal dynamics as revealed by coccolithophores, Mar. Micropaleontol., 29, 351-366, 1997.

Frappier, A., Sahagian, D., Gonzalez, L. A., and Carpenter, S. J.: El Niño events recorded by stalagmite carbon isotopes, Science, 298, 565-565, 2002.

Giraudeau, J.: Distribution of Recent Nannofossils beneath the Benguela System - Southwest African Continental-Margin, Mar. Geol., 108, 219-237, 1992.

Giraudeau, J., Monteiro, P. M. S., and Nikodemus, K.: Distribution and malformation of living coccolithophores in the Northern Benguela upwelling system off Namibia, Mar. Micropaleontol., 22, 93-110, 1993.

Graham, N. E. and White, W. B.: The El-Niño Cycle: a natural oscillator of the Pacific ocean-atmosphere system, Science, 240, 1293-1302, 1988.

Grelaud, M., Beaufort, L., Cuven, S., and Buchet, N.: Glacial to interglacial primary production and El NiñoSouthern Oscillation dynamics inferred from coccolithophores of the Santa Barbara Basin, Paleoceanography, 24, PA1203, doi:10.1029/2007PA001578, 2009.

Haidar, A. T. and Thierstein, H. R.: Coccolithophore dynamics off Bermuda (N. Atlantic), Deep-Sea Res. Pt. II, 48, 1925-1956, 2001.

Hendershott, M. C. and Winant, C. D.: Surface circulation in the Santa Barbara Channel, Oceanography, 9, 114-121, 1996.

Houghton, S. D. and Guptha, M. V. S.: Monsoonal and Fertility Controls on Recent Marginal Sea and Continental-Shelf Coccolith Assemblages from the Western Pacific and Northern Indian Oceans, Mar. Geol., 97, 251-259, 1991.

Huguet, C., Schimmelmann, A., Thunell, R., Lourens, L. J., Damste, J. S. S., and Schouten, S.: A study of the TEX86 paleothermometer in the water column and sediments of the Santa Barbara Basin, California, Paleoceanography, 22, PA3203, doi:10.1029/2006PA001310, 2007.

Hutchins, D. A., DiTullio, G. R., Zhang, Y., and Bruland, K. W.: An iron limitation mosaic in the California upwelling regime, Limnol. Oceanogr., 43, 1037-1054, 1998.

Iglesias-Rodriguez, M. D., Halloran, P. R., Rickaby, R. E. M., Hall, I. R., Colmenero-Hidalgo, E., Gittins, J. R., Green, D. R. H., Tyrrell, T., Gibbs, S. J., von Dassow, P., Rehm, E., Armbrust, E. V., and Boessenkool, K. P.: Phytoplankton Calcification in a High- $\mathrm{CO}_{2}$ World, Science, 320, 336-340, doi:10.1126/science.1154122, 2008.

Ingall, E. and Jahnke, R.: Evidence for enhanced phosphorus regeneration from marine sediments overlain by oxygen depleted 
waters, Geochim. Cosmochim. Ac., 58, 2571-2575, 1994.

Johnson, K. S., Chavez, F. P., and Friederich, G. E.: Continentalshelf sediment as a primary source of iron for coastal phytoplankton, Nature, 398, 697-700, 1999.

Jones, P. D. and Mann, M. E.: Climate over past millennia, Rev. Geophys., 42, RG2002, doi:10.1029/2003RG000143, 2004.

Kaplan, A., Cane, M. A., Kushnir, Y., Clement, A. C., Blumenthal, M. B., and Rajagopalan, B.: Analyses of global sea surface temperature 1856-1991, J. Geophys. Res.-Oceans, 103, 1856718589, 1998.

Kincaid, E., Thunell, R. C., Le, J., Lange, C. B., Weinheimer, A. L., and Reid, F. M. H.: Planktonic foraminiferal fluxes in the Santa Barbara Basin: response to seasonal and interannual hydrographic changes, Deep-Sea Res. Pt. II, 47, 1157-1176, 2000.

Kinkel, H., Baumann, K. H., and Cepek, M.: Coccolithophores in the equatorial Atlantic Ocean: response to seasonal and Late Quaternary surface water variability, Mar. Micropaleontol., 39, 87-112, 2000.

Knappertsbusch, M., Cortes, M. Y., and Thierstein, H. R.: Morphologic variability of the coccolithophorid Calcidiscus leptoporus in the plankton, surface sediments and from the Early Pleistocene, Mar. Micropaleontol., 30, 293-317, 1997.

Langer, G., Geisen, M., Baumann, K. H., Klas, J., Riebesell, U., Thoms, S., and Young, J. R.: Species-specific responses of calcifying algae to changing seawater carbonate chemistry, Geochem. Geophy. Geosy., 7, Q09006, doi:10.1029/2005GC001227, 2006.

Latif, M. and Barnett, T. P.: Causes of decadal climate variability over the North Pacific and North-America, Science, 266, 634637, 1994.

Lluch-Belda, D., Lluch-Cota, D. B., and Lluch-Cota, S. E.: Scales of interannual variability in the California current system: Associated physical mechanisms and likely ecological impacts, Cal. Coop. Ocean. Fish., 44, 76-85, 2003.

Mantua, N. J., Hare, S. R., Zhang, Y., Wallace, J. M., and Francis, R. C.: A Pacific interdecadal climate oscillation with impacts on salmon production, B. Am. Meteorol. Soc., 78, 1069-1079, 1997.

McIntyre, A. and Be, A. W. H.: Modern Coccolithophoridae of Atlantic Ocean-I. Placoliths and Cyrtoliths, Deep-Sea Res., 14, 561-597, 1967.

McIntyre, A., Be, A. W. H., and Roche, M. B.: Modern Pacific Coccolithophoridae a paleontological thermometer, T. New York Acad. Sci., 32, 720-731, 1970.

McLain, D. R. and Thomas, D. H.: Year-to-year fluctuations of the California Countercurrent and effect on marine organisms, Cal. Coop. Ocean. Fish., 24, 165-181, 1983.

Miller, A. J., McWilliams, J. C., Schneider, N., Allen, J. S., Barth, J. A., Beardsley, R. C., Chavez, F. P., Chereskin, T. K., Edwards, C. A., Haney, R. L., Kelly, K. A., Kindle, J. C., Ly, L. N., Moisan, J. R., Noble, M. A., Niiler, P. P., Oey, L. Y., Schwing, F. B., Shearman, R. K., and Swenson, M. S.: Observing and modelling the California Current System, EOS T. Am. Geophys. Un., 80, 533-539, 1999.

Miller, A. J. and Schneider, N.: Interdecadal climate regime dynamics in the North Pacific Ocean: theories, observations and ecosystem impacts, Prog. Oceanogr., 47, 355-379, 2000.

Minobe, S.: Spatio-temporal structure of the pentadecadal variability over the North Pacific, Prog. Oceanogr., 47, 381-408, 2000.

Mitchellinnes, B. A. and Winter, A.: Coccolithophores: a ma- jor phytoplankton component in mature upwelled waters off the Cape Peninsula, South-Africa in March, 1983, Mar. Biol., 95, 25-30, 1987.

Müller, M. N., Antia, A. N., and LaRoche, J.: Influence of cell cycle phase on calcification in the coccolithophore Emiliania huxleyi, Limnol. Oceanogr., 53, 506-512, 2008.

Nederbragt, A. J., Thurow, J. W., and Bown, P. R.: Paleoproductivity, ventilation, and organic carbon burial in the Santa Barbara Basin (ODP Site 893, off California) since the last glacial, Paleoceanography, 23, PA1211, doi:10.1029/2007PA001501, 2008.

Okada, H. and Honjo, S.: The distribution of oceanic coccolithophorids in the Pacific, Deep-Sea Res. Pt. I, 20, 355-374, 1973.

Okada, H. and McIntyre, A.: Seasonal Distribution of Modern Coccolithophores in the Western North-Atlantic Ocean, Mar. Biol., 54, 319-328, 1979.

Paasche, E.: Roles of nitrogen and phosphorus in coccolith formation in Emiliania huxleyi (Prymnesiophyceae), Eur. J. Phycol., 33, 33-42, 1998.

Paasche, E.: A review of coccolithophorid Emiliania huxleyi (Prymnesiophyceae), with particular reference to growth, coccolith formation, and calcification-photosynthesis interactions, Phycologia, 40, 503-529, 2002.

Paillard, D., Labeyrie, L., and Yiou, P.: Macintosh program performs time-series analysis, EOS T. Am. Geophys. Un., 77, 379, 1996.

Reynolds, R. W., Rayner, N. A., Smith, T. M., Stokes, D. C., and Wang, W. Q.: An improved in situ and satellite SST analysis for climate, J. Climate, 15, 1609-1625, 2002.

Riebesell, U., Zondervan, I., Rost, B., Tortell, P. D., Zeebe, R. E., and Morel, F. M. M.: Reduced calcification of marine plankton in response to increased atmospheric $\mathrm{CO}_{2}$, Nature, 407, 364-367, 2000.

Roemmich, D. and McGowan, J.: Climatic Warming and the Decline of Zooplankton in the California Current, Science, 267, 1324-1326, 1995.

Schimmelmann, A., Lange, C. B., and Berger, W. H.: Climayically controlled marker layers in Santa Barbara Basin sediments and fine-scale core-to-core correlation, Limnol. Oceanogr., 35, 165173, 1990.

Schimmelmann, A., Lange, C. B., Roark, E. B., and Ingram, B. L.: Resources for paleoceanographic and paleoclimatic analysis: A 6,700-year stratigraphy and regional radiocarbon reservoir-age (AR) record based on varve counting and ${ }^{14} \mathrm{C}$-AMS dating for the Santa Barbara Basin, offshore California, USA, J. Sediment. Res., 76, 74-80, doi:10.2110/JSR.2006.04, 2006.

Schulz, K. G., Rost, B., Burkhardt, S., Riebesell, U., Thoms, S., and Wolf-Gladrow, D. A.: The effect of iron availability on the regulation of inorganic carbon acquisition in the coccolithophore Emiliania huxleyi and the significance of cellular compartmentation for stable carbon isotope fractionation, Geochim. Cosmochim. Ac., 71, 5301-5312, 2007.

Schulz, M. and Mudelsee, M.: REDFIT: estimating red-noise spectra directly from unevenly spaced paleoclimatic time series, Comput. Geosci., 28, 421-426, 2002.

Sciandra, A., Harlay, J., Lefèvre, D., Lemée, R., Rimmelin, P., Denis, M., and Gattuso, J.-P.: Response of coccolithophorid Emiliania huxleyi to elevated partial pressure of $\mathrm{CO}_{2}$ under nitrogen limitation, Mar. Ecol.-Prog. Ser., 261, 111-122, 
doi:10.3354/MEPS261111, 2003.

Silva, A., Palma, S., and Moita, M. T.: Coccolithophores in the upwelling waters of Portugal: Four years of weekly distribution in Lisbon bay, Cont. Shelf Res., 28, 2601-2613, 2008.

Smith, T. M. and Reynolds, R. W.: Extended reconstruction of global sea surface temperatures based on COADS data (18541997), J. Climate, 16, 1495-1510, 2003.

Stahle, D. W., D’Arrigo, R. D., Krusic, P. J., Cleaveland, M. K., Cook, E. R., Allan, R. J., Cole, J. E., Dunbar, R. B., Therrell, M. D., Gay, D. A., Moore, M. D., Stokes, M. A., Burns, B. T., Villanueva-Diaz, J., and Thompson, L. G.: Experimental dendroclimatic reconstruction of the Southern Oscillation, B. Am. Meteorol. Soc., 79, 2137-2152, 1998.

Takahashi, K. and Okada, H.: Environmental control on the biogeography of modern coccolithophores in the southeastern Indian Ocean offshore of Western Australia, Mar. Micropaleontol., 39, 73-86, 2000.

Tegner, M. J., Dayton, P. K., Edwards, P. B., and Riser, K. L.: Is there evidence for long-term climatic change in southern California kelp forests?, Cal. Coop. Ocean. Fish., 37, 111-126, 1996.

Thunell, R. C.: Particle fluxes in a coastal upwelling zone: sediment trap results from Santa Barbara Basin, California, Deep-Sea Res. Pt. II, 45, 1863-1884, 1998.

Tudhope, A. W., Shimmield, G. B., Chilcott, C. P., Jebb, M., Fallick, A. E., and Dalgleish, A. N.: Recent changes in climate in the far western equatorial Pacific and their relationship to the Southern Oscillation; Oxygen isotope records from massive corals, Papua New Guinea, Earth Planet. Sc. Lett., 136, 575-590, 1995.

Tudhope, A. W., Chilcott, C. O., McCulloch, M. T., Cook, E. R., Chappell, J., Ellam, R. M., Lea, D. W., Lough, J. M., and Shimmield, G. B.: Variability in the El Niño-Southern Oscillation Through a Glacial-Interglacial Cycle, Science, 291, 1511-1517, 2001.

van Bleijswijk, J. D. L., Kempers, E. S., Van Der Wal, P., Westbroek, P., Egge, J. K., and Lukk, T.: Standing stocks of PIC, POC, PON and Emiliania huxleyi coccospheres and liths in seawater enclosures with different phosphate loadings, Sarsia, 79, 307-317, 1994.
Van Emburg, P.: Coccolith formation in Emiliania huxleyi, Ph.D. thesis, Leiden University, 1989.

Weinheimer, A. L. and Cayan, D. R.: Radiolarian assemblages from Santa Barbara Basin sediments: Recent interdecadal variability, Paleoceanography, 12, 658-670, 1997.

Winter, A., Jordan, R. W., and Roth, P. H.: Biogeography of living coccolithophores in ocean waters, in: Coccolithophores, edited by: Siesser, A. W. a. W. G., Cambridge University Press, Cambridge, 161-177, 1994.

Woodruff, S. D., Diaz, H. F., Elms, J. D., and Worley, S. J.: COADS Release 2 data and metadata enhancements for improvements of marine surface flux fields, Phys. Chem. Earth, 23, 517-526, 1998.

Young, J. R.: Functions of coccoliths, in: Coccolithophores, edited by: Siesser, A. W. a. W. G., Cambridge University Press, Cambridge, 63-82, 1994.

Young, J. R., Geisen, M., Cros, L., Kleijne, A., Sprengel, C., Probert, I., and Ostergaard, J. B.: A guide to extant coccolithophore taxonomy, Int. Nannoplankton Assoc., London, 125 pp., 2003.

Zebiak, S. E. and Cane, M. A.: A Model El-Niño Southern Oscillation, Mon. Weather Rev., 115, 2262-2278, 1987.

Zhang, Y., Wallace, J. M., and Battisti, D. S.: ENSO-like interdecadal variability: 1900-93, J. Climate, 10, 1004-1020, 1997.

Ziveri, P., Thunell, R. C., and Rio, D.: Seasonal changes in coccolithophore densities in the southern California Bight during 19911992, Deep-Sea Res. Pt. I, 42, 1881-1903, 1995.

Zondervan, I., Zeebe, R. E., Rost, B., and Riebesell, U.: Decreasing marine biogenic calcification: A negative feedback on rising atmospheric $p \mathrm{CO}_{2}$, Global Biogeochem. Cy., 15, 507-516, 2001.

Zondervan, I.: The effects of light, macronutrients, trace metals and $\mathrm{CO} 2$ on the production of calcium carbonate and organic carbon in coccolithophores - A review, Deep-Sea Res. Pt. II, 54, 521537, 2007. 